\title{
EFFECT OF THE MATERIAL OF PRIMARY PACKAGING CONTAINERS ON PROVIDING VISUAL INSPECTION OF PHARMACEUTICAL PRODUCTS
}

\author{
Victor Demyanenko $^{1}$, Dmitry Demyanenko $^{1}$, Svetlana Breusova ${ }^{1}$, Inna Baranova ${ }^{1}$, \\ Liliya Karpenko ${ }^{2}$
}

${ }^{1}$ Department of Commodity Science, Faculty of Pharmacy,

National University of Pharmacy, Ukraine

${ }^{2}$ Department of Social Pharmacy, Faculty of Pharmacy,

National University of Pharmacy, Ukraine

\section{ABSTRACT}

Introduction: Nowadays, all over the world the requirements for drug quality have become more and more strict and its evaluation is one of the most important tasks. Usually, input quality control of medicines and other groups of goods is carried out organoleptically (mainly visually) by authorized people from pharmaceutical establishments. Primary packaging is one of the most critical components in this process, because it strongly influences the possibility of visual control of goods and, of course, it should be transparent.

The aim of this article was to analyze primary packaging of some drugs and the possibility of their identification and quality evaluation.

Materials and Methods: Objects of this study were primary packages of 65 randomly chosen drugs produced by some leading manufacturers in different dosage forms. Inspection analysis of the quality of the researched medicinal products was provided in 8 steps: checking of the accompanying documents, checking the quantity of the goods, organoleptic control of packaging, checking of labeling, checking of barcodes, checking of completeness, visual control of a product, accompanying documentation for the intake of the goods.

Results and Conclusion: All investigated drugs passed the first 6 stages of inspection analysis positively. 46 samples out of 65 (or 71\%) could not be visually controlled (stage 7) and their appearance was impossible to check because of the non-transparency of the containers. When separated into different forms, the distribution is the following: $53 \%$ of studied tablet drugs, $88 \%$ of eye drops and $100 \%$ of suppositories cannot be evaluated visually.

Keywords: visual inspection, drugs, packaging materials, primary packaging, quality

Address for correspondence:

Dmitry Demyanenko,

Faculty of Pharmacy

National University of Pharmacy

12 Kulykivska St

Kharkiv, Ukraine

e-mail:aeia1@mail.ru

Received: May 16, 2016

Accepted: June 19, 2016

\section{INTRODUCTION}

The range of pharmaceutical products on the Ukrainian market is formed by both domestic and imported drugs. Nowadays, consumer requirements for drug quality are significantly increasing. Due to economical imbalance substantial reduction in the production volume has occured. Meanwhile, the market is full of low-quality, substandard and counterfeit goods. According to the data of the Organi- 
Victor Demyanenko, Dmitry Demyanenko, Svetlana Breusova et al.

zation for Economic Co-operation and Development (OECD) the international trade of counterfeit goods reaches $\$ 200$ billion per year (1). A significant decline in the living standards has affected their entry into the domestic market. Most buyers cannot afford expensive brand drugs, which is why counterfeit drugs is directed to them. As a consequence, in developing countries they can take up to $35 \%$ of the pharmaceutical market (2).

Use of such products is associated with a significant risk for the life and health of the consumers. Counterfeit drugs are the major cause of morbidity, mortality, and loss of confidence in the healthcare system (3). According to data (4), most of the counterfeit reports are related to antibiotics, antiprotozoals, hormones, and steroids. Therefore, the challenge of supplying the domestic market with high-quality drugs is very urgent now.

Manufacturers have to develop more and more advanced methods to prevent counterfeiting of their own goods. These means can be divided into two main groups: visible and hidden ones. The first group involves advanced barcodes, holograms, three-dimensional images, special inks, watermarks (5-8). The second group includes radio-frequency identification (RFID) tags, UV-sensitive hidden paints, biometric fingerprints, etc. (8-12). It's important for all of these means to be able to control the goods and their authenticity during the entire supply chain and finally in pharmacies.

The quality level of the products is a relative characteristic based on a comparison of actual indicators of the product quality with standard ones.

Nowadays, all over the world consumer requirements for drug quality have become much stricter and its determination and methods of its expression are some of the most important tasks of our time (13).

The quantitative characteristics of the products are characterized by quality parameters. It's possible to define either single or comprehensive indexes. Comprehensive evaluation characterizes the overall quality level of the tested product and allows the drawing of conclusions about the conformity of its properties to the consumer needs and the requirements of normative documents $(14,15)$.
Legal regulation of the drug control procedures in Ukraine is provided by President Decrees and legal acts of the Ministries, which adopt National strategies, concepts and programs (16-22). Currently, there are four supplements to the State Pharmacopoeia of Ukraine (in 2004, 2008, 2009, 2011), among which the $1^{\text {st }}$ supplement which establishes the requirements for drugs containers (23).

At present, quality control of medicinal products is carried out under order № 677 of the Ministry of Public Health of Ukraine dated 29.09.2014 "On approval of the rules for quality control of medicinal products in wholesale and retail trade" (22).

Input quality control of medicines in retail and wholesale trade is carried out organoleptically (mainly visually) by authorized people from pharmaceutical establishments having a license for providing business activities in the wholesale and retail trade of medicines. The visual method is based on the use of information obtained by the senses - sight, hearing, smell and touch.

The organoleptic method has certain advantages. First, it does not require special instruments, devices, and complex equipment. Second, it provides fast indicating and is always used first, even sometimes eliminating the need for measuring methods especially when taste, flavors, smells, colors, consistence of perfumes and cosmetics are tested. Its main disadvantage is subjectivity. In order to reduce it one uses quantitative methods to evaluate some quality parameters (24).

At the reception of goods an authorized person checks:

* compliance of the drugs to shipping documents regarding quantity, dosage, batch numbers, expire dates, registration status, name, dosage form, manufacturer. Each batch of a drug must be accompanied with copies of the batch quality certificate which is given by the manufacturer (for imported medicines - by the foreign manufacturer together with a stamped conclusion about the quality of the imported drug given in Ukraine);

* labeling of the secondary and primary packaging, presence of a leaflet for the drug specifying instructions for its use, appearance and integrity of the secondary packaging, uniformity, ab- 
sence of damages, quality of the packaging materials. If necessary, drugs are tested after opening the package, for their size, shape, color, homogeneity, quantity of units in the package, presence or absence of impurities.

If the result from the input control is positive, an authorized person gives permission for the distribution of the drug batches obtained.

In case of any doubt about the quality of the medicines during the performance of a visual inspection, an authorized person takes samples from the suspicious drugs and sends them to the Territorial Inspectorate for Drug Quality and Safety Control to provide full laboratory examination. Until obtaining the conclusion about the quality of the suspicious batches they are kept within a quarantined area (premise), separately from other products.

Based on the above-mentioned, it can be concluded that the inspection analysis lies in the evaluation of shipping documents, labeling, and appearance of secondary and sometimes primary packaging, but the organoleptic analysis of certain drugs is made only when required. This suggests that quality evaluation of drug forms may be skipped.

Therefore, most publications about the falsification of medicines are focused on assessing the quality of the secondary packaging materials and labeling (25-27).

In practice, only a few studies were conducted and several papers about the effects of the primary packaging materials on the organoleptic properties of drugs during input control were published $(28,29)$.

Thus, there is a need for a comprehensive inspection analysis to determine the quality of medicines produced in Ukraine and abroad.

Sale of medicines and medical devices is not possible without their pre-packaging.

Primary packaging is one of the most important components and functions of the drug production process. It protects them from the environment and ensures the preservation of the properties during the entire "life cycle" of a drug - from manufacturing to consumption by a patient.

The packaging consists of a container, a product placed therein, a closure and labeling.

The main requirements to primary packaging are conventionally divided into:
1. Design.

Primary packaging should be designed to:

* protect a drug from adverse environmental conditions;

* protect against mechanical impacts;

* be tight and stable;

* protect against microbial contamination;

* provide metered or separated withdrawing of a drug;

* have first opening control;

* have good appearance and convenience in use;

* be safe.

2. Requirements of the materials.

Packaging materials used for the packing of medicinal products must be authorized for use by the Ministry of Public Health of Ukraine, and also comply with specified requirements, not affect the stability and pharmacological properties of drugs, not contain carcinogenic and toxic components, heavy metals, arsenic and other harmful impurities in quantities exceeding the standard norms, as well as dyes that are not permitted to use; should be free of any foreign smell and microbial contamination above the established norms. The packaging of sterile medical products should be composed of materials resistant to pre-sterilization, withstand sterilization methods specified by the manufacturing process and must not contain mechanical impurities.

3. The specific requirements for packaging are determined mainly by the chemical composition of a drug and its production process.

Containers for packaging of medicines containing hygroscopic, volatile and oxidizing agents should provide moisture, vapor and gas barrier within the relevant indicators of normative documents; for drugs of fatty base - should have low fat (oil) penetrability; for light sensitive drugs - should be opaque. For injection solutions, eye drops, on the contrary, packaging should be transparent to make inclusion control possible.

4. General requirements for packaging (30):

* clarity of the texts printed on a packaging;

* availability of instructions for use;

* attractive color design;

* availability of the first opening control;

* safety of use; 
* absence of sharp corners and edges.

The additional requirements to primary packaging for pharmaceuticals are regulated by normative documentation including:

* composition of the packaging material indicating, in particular, qualitative composition of the different parts of a package, as well as non-plastic parts;

* description of a closing element (composition and test methods) including, if necessary, description of a waterproof and airtight seal;

* method of package opening and, if necessary, devices ensuring safety;

* container information (multidose or monodose) and measuring devices;

* description of the closing element which prevents opening of a container by children.

Considering all of the above-mentioned information, the aim of this article was to study influence of primary packaging materials on the identification of medicines and the evaluation of their quality.

\section{OBJECTS AND METHODS OF RESEARCH}

Objects of this study were the primary packages of randomly chosen drugs produced by some of the leading manufacturers in different forms. The subject of the study was the possibility of identification of this drugs and the evaluation of their quality indicators.

Inspection analysis of the quality level of the researched medicinal products was provided in the following steps (Fig. 1).

Stage 1. Checking of the accompanying documents for incoming goods.

The documentary analysis has the aim to evaluate the commodity characteristics of the goods based on the information in the accompanying shipping documents. Checking the completeness of the accompanying documents (invoices, waybills, tax waybills, batch (lot) quality certificates, list of medicinal products and other documents confirming the amount and the quality of incoming goods) as well as the correctness of their drawing up. The authenticity and correctness of the filled out documents are evaluated by the presence of the required data, signatures, stamps of the supplying company, its name

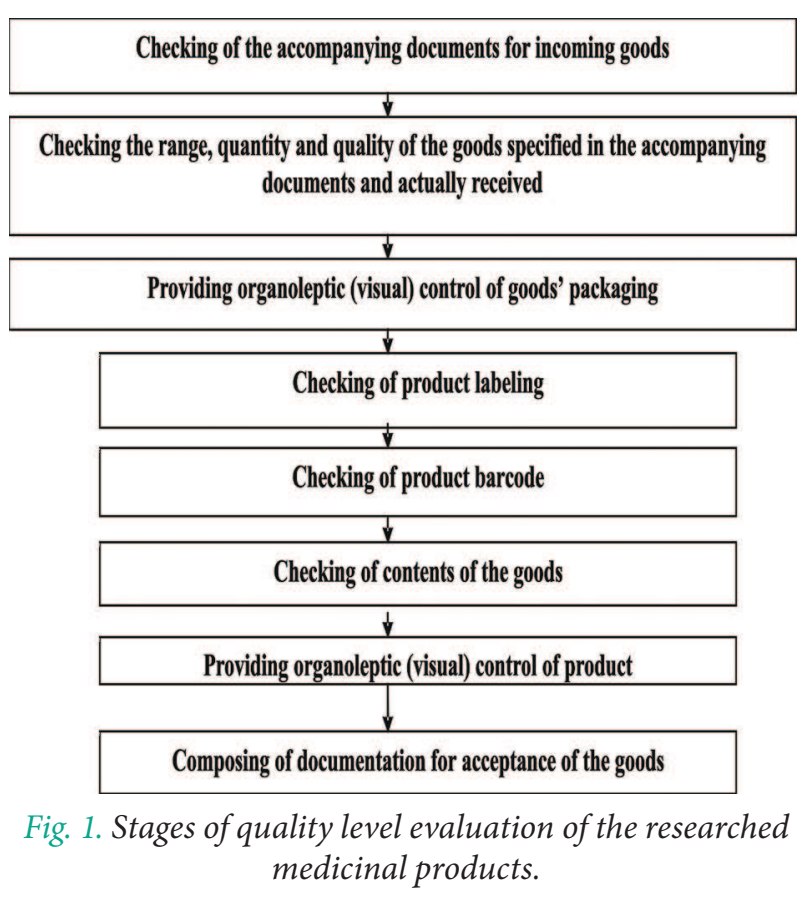

and address. In addition, cross-verification of the main characteristics of the goods specified in various documents (invoices, batch and conformity certificates) and labeling is provided.

Stage 2. Checking the range, quantity and quality of the goods specified in the accompanying documents and the ones actually received.

The assortment analysis of goods has the aim to verify their conformity to name, article, trademark specified in the labeling and the accompanying documents.

Checking the goods by their quantity is carried out by comparing those specified in the orders, accompanying shipping documents of the supplier and the ones actually received.

The quantity of products is counted in the units specified in the supply contracts.

Quality control is provided by comparing the quality of the incoming goods, their completeness, packaging and labeling with the requirements of the standards, as well as the contract terms and the data of supplier's accompanying shipping documents confirming quality of these products (e.g., drug batch certificates).

Stage 3. Providing organoleptic (visual) control of the product packaging. 
Packaging protects a product from the external environment. Its integrity and state influence the quantity, quality and safety of the goods.

Packaging control includes a number of measures to check integrity, quality of primary and secondary packaging, and their compliance with the physical and chemical properties of the drugs.

Checking the integrity and quality of secondary packaging begins from a detection of unusual sounds such as broken glass and others. Then attention is paid to size, shape (top, sides and bottom, possible deformations and damages as a result of mechanical stress), conformity to storage conditions (elevated temperature, humidity, etc.), quality of the material from which the packaging is made and its print design (distinct markings, color characteristics, possible change of colors). The presence or absence of defects is checked: local discoloration, dirt, dents, cracks, damage, leakage of contents, signs of forgery or unauthorized opening, presence or absence of protective signs or seals, sometimes visible only under special lighting (e.g., UV), etc.

Primary packaging is checked for integrity of the container, presence of seals, first opening control, labeling.

Stage 4. Checking of product labeling.

Labeling is intended to identify products as well as to provide information about the manufacturer, qualitative and quantitative characteristics of a product. Special requirements are applied to labeling: distinct and well-defined text and images, visibility, compliance with the consumer properties of the goods, authenticity (the information given on a label must correspond to the quantity and quality of the goods), manufacturer's name, country of origin and others.

During the checking process the information on the labeling is analyzed and it must be identical to that specified in the accompanying shipping documents.

When checking the labeling of medicinal products, attention should be paid to matching the drug batch number on the primary, secondary packaging and the one in the accompanying shipping documents. It's necessary to ensure that the manufacturing of this drug batch has not been discontinued.
The labeling on the secondary packaging of a finished medicinal product includes: country of the manufacturer, manufacturer's name, their trademark and address, name of the finished medicinal product in Ukrainian and/or Russian and/or English and/or Latin, form of the medicine, quantity of the finished product, concentration (activity or dose), qualitative and quantitative composition of the ingredients, way of administration, batch number, expiration date, registration number, storage conditions, barcode.

Labeling on ampoules, syringe tubes and pipettes includes the name of the finished product, concentration or activity, quantity of the drug, batch number, expiration date. The following should be indicated on a tube: the name of the drug, dose (or concentration or activity of the drug), batch number, expiration date, the proprietor of the registration certificate.

Labeling of drugs with Braille font: according to the Order of the Ministry of Public Health of Ukraine № 722 dated 25.08.2010 "About approval of the labeling of medicinal products with Braille font", which was enforced on 26.11.2010, requirements for drug labeling were introduced considering the Directive of the European Parliament and Council of Europe N 2004/27/EC from 31.03.2004.

Braille marking is applied to the secondary packaging of medicinal products and should be presented in Ukrainian and by the applicant's request in Russian or another language.

Braille marking includes:

* name of the drug (for drugs in one form and dose as well as for herbal preparations this is enough);

* dose of the active substance (if a drug is produced in multiple doses);

* form (if a drug is produced in multiple forms). Stage 5. Checking the product barcode.

When analyzing barcodes of goods it's necessary to check:

1. Number of barcodes. Often, only one barcode type is applied to the packaging such as European Article Numbering (EAN) or Universal Product Code (UPC). Use of two barcode types is acceptable if a manufacturer is registered in two associations. In this case, they 
Victor Demyanenko, Dmitry Demyanenko, Svetlana Breusova et al.

should be printed on opposite sides of the package.

2. Location of the barcode. The location of a barcode on a package (or a product) must conform to the requirements of the national standards.

Generally, it's recommended to place the barcode mark on the back side of a package (product) in the lower right corner. It's allowed to place it in the lower right quadrant of any other side of a packaging. General Specifications GS1 show strict requirements: the minimum distance of a barcode (including a stabilization zone) from any edge of a package (product) must be not less than $8 \mathrm{~mm}$ and not more than $102 \mathrm{~mm}$.

The standard orientation of a barcode is horizontal: the digits printed below the barcode should be oriented in the same direction as the text or graphic design of the packaging.

When a barcode is located on a curved surface, the angle between the tangents to the curved surfaces, one of which passes through the midpoint of a barcode and another one - through the outer edge of barcode limiting zone, should not exceed $30^{\circ}$.

A barcode should not be placed onto other labeling elements (text, images, perforations).

3. Check of the digits and their correctness is determined by scanner or by calculation. A failure may indicate a technical error when typing a barcode or a falsification of a product.

4. Dimensions of the barcode. Codes recommended for application onto the packaging of medicines are divided by their size in small, normal and large ones. The most commonly used standard size is $10 \mathrm{~mm}$ in height, $27 \mathrm{~mm}$ or $36 \mathrm{~mm}$ in length.

5. Color of barcode marks. A barcode should be black, blue, green or dark brown. Shades of red and yellow colors for bars are not allowed as they cannot be read by a scanner. Background color should be white but it can also be yellow or beige.

6. Print quality of the barcode. Bars should be uniform in color and contrast, without blurs or lighter spots inside.

7. Compliance with the code list registered in the EAN association. The first two or three digits of a barcode should correspond to an EAN number assigned to the country. The origin and identification of a product manufactured in a certain country should be checked. Non-compliance of these digits is a sign of product falsification.

Stage 6. Checking of the contents of the goods.

Checking for completeness means to verify the compliance of a set of the products to the list of individual components specified in the operating manuals or related documents.

The term completeness includes the combination of elements forming a single product unit with certain consumer properties of the goods, and these elements are used as a whole but not separately.

When checking the completeness of the finished medical product, presence or absence of instructions (leaflets), dispensers and other devices for the use of this drug are verified.

Stage 7. Providing organoleptic (visual) control of a product.

General organoleptic characteristics are as follows: appearance, taste, smell, consistency. Appearance is the comprehensive parameter including shape, color, state of a surface. Appearance is not only easy to check but also one of the most important criteria for a comprehensive evaluation of product quality. It is the first stage of product identification by manufacturers, sellers and buyers. Organoleptic control of medicine forms is carried out using the parameter in monographs "Appearance" or "Description" $(9,31,32)$.

\section{Requirements for tablets.}

The evaluation of tablet quality begins with a check of their appearance (organoleptic properties) which is affected by the following factors during production: compressing conditions, adhesion and cohesion properties of the mass to be compressed, its moisture content, particle size distribution, surface and precision of the press tools, method of coating, etc.

The following defects should be absent on tablets: protrusions (projections on the surface or adhering powder particles); hollows (craters, crumbled parts of tablets); dirt or dust; marbling (non-uni- 
form color, local color changes); chips (different layers in the tablets, reduced thickness); agglutination (sticking of tablets together or their binding to damaged surfaces); crumbling; deformations (non-round shape); scratches; coating defects (non-uniform coating surface, varying thickness, shift of the core from center).

Tablets should have a round or other shape with flat or biconvex surfaces, unbroken edges; the surface should be smooth and uniform in color unless otherwise indicated in the reference documentation (32).

\section{Requirements for suppositories.}

Depending on the structure and characteristics of the body cavities suppositories may have various geometric shapes and sizes. They are divided into rectal, vaginal suppositories and sticks. Rectal suppositories are administered into the rectum, vaginal ones - into the vagina, and sticks - into urinary and other canals (cervix, ear canal, fistulas and wounds). All suppositories, especially rectal and urethral ones, should have sufficient hardness allowing them to overcome the resistance of tissues and sphincters; otherwise they would become deformed and their use becomes impossible.

Suppositories should have a proper uniform shape, smooth consistency and sufficient hardness, which provides ease of use, their color and smell should correspond to the properties of the ingredients. Uniform consistency is checked visually for absence of foreign materials or coarse surfaces. Pres- ence of air bubbles or funnel-shaped hollows are acceptable.

Requirements for eye drops and injection solutions.

Eye drops and injection solutions should not contain mechanical impurities visible with a naked eye. They should be transparent, sterile, isotonic and stable, suspension drops may form a precipitate which should be re-suspended easily by agitation forming a stable suspension. To control visible particles, 60 ampoules from a batch are randomly chosen. Presence of visible mechanical impurities is allowed in no more than one item (31).

Stage 8. Preparing the documentation for the reception of the goods.

Based on the results from the inspection analysis, commission members prepare corresponding documents about the reception of the goods by quantity, quality and completeness. These acts are compiled separately by each supplier and for each batch of goods received according the accompanying shipping documents.

To provide a study of quality indicators of some medicines to conform them to the requirements of the inspection analysis, we took randomly 65 samples of drugs produced by different manufacturers in various forms. These drugs are presented in the Table 1. Their compliance with the established organoleptic characteristics was determined by the procedures specified in current reference documents, pharmacopoeian monographs and others.

Table 1. Test samples of medicines

\begin{tabular}{|c|c|c|c|}
\hline $\begin{array}{l}\text { Sample } \\
\text { number }\end{array}$ & Form & Primary packaging & $\begin{array}{l}\text { Name of the product } \\
\text { and the manufacturer }\end{array}$ \\
\hline \multicolumn{4}{|c|}{ Sandoz, Lek, Poland, Austria, Romania, Slovenia } \\
\hline 1 & tablets & $\begin{array}{l}\text { non-transparent } \\
\text { blister pack }\end{array}$ & $\begin{array}{l}\text { Rami Sandoz } 5 \text { mg, } 10 \text { mg, } 25 \text { mg (Lek S.A., } \\
\text { Poland) }\end{array}$ \\
\hline 2 & tablets & $\begin{array}{l}\text { non-transparent } \\
\text { blister pack }\end{array}$ & $\begin{array}{l}\text { Azithro Sandoz }{ }^{\circledast}, 250 \mathrm{mg}, 500 \mathrm{mg} \text {, (Sandoz, } \\
\text { Romania) }\end{array}$ \\
\hline 3 & tablets & $\begin{array}{l}\text { non-transparent } \\
\text { blister pack }\end{array}$ & $\begin{array}{l}\text { Cefuroxim Sandoz }{ }^{\circledast}, 250 \mathrm{mg}, 500 \mathrm{mg} \text {, (Sandoz, } \\
\text { GmBH) }\end{array}$ \\
\hline 4 & tablets & $\begin{array}{l}\text { transparent } \\
\text { blister pack }\end{array}$ & $\begin{array}{l}\text { Nakom } 25 \text { mg / } 250 \text { mg (Lek Pharmaceutical } \\
\text { Company, Slovenia) }\end{array}$ \\
\hline 5 & tablets & $\begin{array}{l}\text { transparent } \\
\text { blister pack }\end{array}$ & $\begin{array}{l}\text { Dicinon } 250 \text { mg (Lek Pharmaceutical Compa- } \\
\text { ny, Slovenia) }\end{array}$ \\
\hline
\end{tabular}


Victor Demyanenko, Dmitry Demyanenko, Svetlana Breusova et al.

\begin{tabular}{|c|c|c|c|}
\hline 6 & tablets & $\begin{array}{l}\text { transparent } \\
\text { blister pack }\end{array}$ & $\begin{array}{l}\text { Ospamox DT }{ }^{\circledast}, 1000 \text { mg, (Sandoz GmBH, } \\
\text { Austria) }\end{array}$ \\
\hline 7 & tablets & $\begin{array}{l}\text { transparent } \\
\text { blister pack }\end{array}$ & $\begin{array}{l}\text { Ospamox }{ }^{\circledR}, 500 \text { mg, } 1000 \text { mg (Sandoz GmBH, } \\
\text { Austria) }\end{array}$ \\
\hline 8 & tablets & $\begin{array}{l}\text { transparent } \\
\text { blister pack }\end{array}$ & Persen (Lek Pharmaceutical Company, Slovenia) \\
\hline \multicolumn{4}{|c|}{ Alcon-Couvreur, Belgium } \\
\hline 9 & eye drops & $\begin{array}{l}\text { white polymeric } \\
\text { non-transparent vial }\end{array}$ & Tobrex $0.3 \%, 5 \mathrm{ml}$ \\
\hline 10 & eye drops & $\begin{array}{l}\text { white polymeric } \\
\text { non-transparent vial }\end{array}$ & Quinax $0.015 \%, 15 \mathrm{ml}$ \\
\hline 11 & eye drops & $\begin{array}{l}\text { white polymeric } \\
\text { non-transparent vial }\end{array}$ & Betoptic S $0.25 \%, 5 \mathrm{ml}$ \\
\hline 12 & eye drops & $\begin{array}{l}\text { white polymeric } \\
\text { non-transparent vial }\end{array}$ & Azopt $1 \%, 5 \mathrm{ml}$ \\
\hline 13 & eye drops & $\begin{array}{l}\text { polymeric non-trans-parent } \\
\text { dropper-vial }\end{array}$ & Maxitrol $5 \mathrm{ml}$ \\
\hline 14 & eye drops & $\begin{array}{l}\text { polymeric transparent } \\
\text { dropper-vial }\end{array}$ & Maxidex $0.1 \%, 5 \mathrm{ml}$ \\
\hline 15 & eye drops & polymeric transparent vial & Mydriacyl $1 \%, 15 \mathrm{ml}$ \\
\hline \multicolumn{4}{|c|}{ Krка Novo-Mesto, Slovenia } \\
\hline 16 & tablets & $\begin{array}{l}\text { non-transparent } \\
\text { blister pack }\end{array}$ & Ampril $2.5 \mathrm{mg}, 5 \mathrm{mg}, 10 \mathrm{mg}$ \\
\hline 17 & tablets & $\begin{array}{l}\text { non-transparent } \\
\text { blister pack }\end{array}$ & $\begin{array}{l}\text { Amlessa } 4 \mathrm{mg} / 5 \mathrm{mg}, 4 \mathrm{mg} / 10 \mathrm{mg} \text {, } \\
8 \mathrm{mg} / 5 \mathrm{mg}, 8 \mathrm{mg} / 10 \mathrm{mg}\end{array}$ \\
\hline 18 & tablets & $\begin{array}{l}\text { non-transparent } \\
\text { blister pack }\end{array}$ & Bisoprolol $5 \mathrm{mg}, 10 \mathrm{mg}$ \\
\hline 19 & tablets & $\begin{array}{l}\text { non-transparent } \\
\text { blister pack }\end{array}$ & Roxera $10 \mathrm{mg}, 20 \mathrm{mg}$ \\
\hline 20 & tablets & $\begin{array}{l}\text { non-transparent } \\
\text { blister pack }\end{array}$ & Atoris $10 \mathrm{mg}, 20 \mathrm{mg}, 30 \mathrm{mg}, 40 \mathrm{mg}$ \\
\hline 21 & tablets & $\begin{array}{l}\text { non-transparent } \\
\text { blister pack }\end{array}$ & $\begin{array}{l}\text { Koriol } 12.5 \mathrm{mg}, 25 \mathrm{mg}, 3.125 \mathrm{mg} \text {, } \\
6,25 \mathrm{mg}\end{array}$ \\
\hline 22 & tablets & $\begin{array}{l}\text { non-transparent } \\
\text { blister pack }\end{array}$ & Nolpasa $20 \mathrm{mg}, 40 \mathrm{mg}$ \\
\hline \multicolumn{4}{|c|}{ Continuation of the Table 1.} \\
\hline 23 & tablets & $\begin{array}{l}\text { non-transparent } \\
\text { blister pack }\end{array}$ & Enap $2.5 \mathrm{mg}, 5 \mathrm{mg}, 10 \mathrm{mg}, 20 \mathrm{mg}$ \\
\hline 24 & tablets & $\begin{array}{l}\text { non-transparent } \\
\text { blister pack }\end{array}$ & Enap H 10 mg \\
\hline 25 & tablets & $\begin{array}{l}\text { non-transparent } \\
\text { blister pack }\end{array}$ & Enap HL $10 \mathrm{mg}, 20 \mathrm{mg}$ \\
\hline 26 & tablets & $\begin{array}{l}\text { transparent } \\
\text { blister pack }\end{array}$ & Vasylil $10 \mathrm{mg}, 20 \mathrm{mg}$ \\
\hline 27 & tablets & $\begin{array}{l}\text { transparent } \\
\text { blister pack }\end{array}$ & Valsakor $80 \mathrm{mg}, 160 \mathrm{mg}, 320 \mathrm{mg}$ \\
\hline 28 & tablets & $\begin{array}{l}\text { transparent } \\
\text { blister pack }\end{array}$ & $\begin{array}{l}\text { Valsakor HD } 160 \mathrm{mg} / 25 \mathrm{mg} \text {, } \\
320 \mathrm{mg} / 25 \mathrm{mg}\end{array}$ \\
\hline 29 & tablets & $\begin{array}{l}\text { transparent } \\
\text { blister pack }\end{array}$ & Lorista $50 \mathrm{mg}, 100 \mathrm{mg}$ \\
\hline
\end{tabular}

Scripta Scientifica Pharmaceutica, vol. 3, No. 1, 2016, pp. 60-72 


\begin{tabular}{|c|c|c|c|}
\hline 30 & tablets & $\begin{array}{l}\text { transparent } \\
\text { blister pack }\end{array}$ & Lorista H $50 \mathrm{mg} / 2.5 \mathrm{mg}$ \\
\hline 31 & tablets & $\begin{array}{l}\text { transparent } \\
\text { blister pack }\end{array}$ & Lorista HD $100 \mathrm{mg} / 25 \mathrm{mg}$ \\
\hline 32 & tablets & $\begin{array}{l}\text { transparent } \\
\text { blister pack }\end{array}$ & Cyprinol $250 \mathrm{mg}, 500 \mathrm{mg}, 750 \mathrm{mg}$ \\
\hline \multicolumn{4}{|c|}{ Berlin-Chemie / Menarini Pharma Gmbh (representative, Germany) } \\
\hline 33 & tablets & $\begin{array}{l}\text { non-transparent } \\
\text { blister pack }\end{array}$ & Lekramen $10 \mathrm{mg}, 20 \mathrm{mg}$ \\
\hline 34 & tablets & $\begin{array}{l}\text { non-transparent } \\
\text { blister pack }\end{array}$ & Berlipril 5 mg, $10 \mathrm{mg}, 20 \mathrm{mg}$ \\
\hline 35 & tablets & $\begin{array}{l}\text { non-transparent } \\
\text { blister pack }\end{array}$ & $\begin{array}{l}\text { L-thyroxine } 75 \text {, L-thyroxine } 50 \text {, } \\
\text { 125, L-thyroxine } 100 \text {, L-thyroxine } 150\end{array}$ \\
\hline 36 & tablets & $\begin{array}{l}\text { non-transparent } \\
\text { blister pack }\end{array}$ & Mezym-forte 10000, 20000 \\
\hline 37 & tablets & $\begin{array}{l}\text { non-transparent } \\
\text { blister pack }\end{array}$ & Dicloberl $50 \mathrm{mg}$ \\
\hline 38 & tablets & $\begin{array}{l}\text { non-transparent } \\
\text { blister pack }\end{array}$ & Berlithion $300 \mathrm{mg}$ \\
\hline 39 & tablets & $\begin{array}{l}\text { transparent } \\
\text { blister pack }\end{array}$ & Corvitol $50 \mathrm{mg}, 100 \mathrm{mg}$ \\
\hline 40 & tablets & $\begin{array}{l}\text { transparent } \\
\text { blister pack }\end{array}$ & Trifas $10 \mathrm{mg}$, Trifas-COR $5 \mathrm{mg}$ \\
\hline 41 & tablets & $\begin{array}{l}\text { transparent } \\
\text { blister pack }\end{array}$ & Nebilet $5 \mathrm{mg}$ \\
\hline 42 & tablets & $\begin{array}{l}\text { transparent } \\
\text { blister pack }\end{array}$ & Falimint $25 \mathrm{mg}$ \\
\hline 43 & tablets & $\begin{array}{l}\text { transparent } \\
\text { blister pack }\end{array}$ & Siofor $500 \mathrm{mg}, 850 \mathrm{mg}, 1000 \mathrm{mg}$ \\
\hline \multicolumn{4}{|c|}{ Pharmak, Ukraine } \\
\hline 44 & eye drops & $\begin{array}{l}\text { white polymeric } \\
\text { non-transparent vial }\end{array}$ & Vial $0.05 \% 10 \mathrm{ml}$ \\
\hline 45 & eye drops & $\begin{array}{l}\text { white polymeric } \\
\text { non-transparent vial }\end{array}$ & Vial light $0.5 \% 10 \mathrm{ml}$ \\
\hline \multicolumn{4}{|c|}{ Continuation of the Table 1.} \\
\hline 46 & eye/ear drops & $\begin{array}{l}\text { white polymeric } \\
\text { non-transparent vial }\end{array}$ & Cypropharm $10 \mathrm{ml}$ \\
\hline 47 & eye drops & $\begin{array}{l}\text { white polymeric } \\
\text { non-transparent vial }\end{array}$ & Ophthymol $5 \mathrm{ml}, 10 \mathrm{ml}$ \\
\hline 48 & eye drops & $\begin{array}{l}\text { white polymeric } \\
\text { non-transparent vial }\end{array}$ & $\begin{array}{l}\text { Dexamethazone-Biopharma 0.1\% } 5 \mathrm{ml}, 10 \mathrm{ml} \\
\text { (Biopharma Ltd., Ukraine) }\end{array}$ \\
\hline \multicolumn{4}{|c|}{ Lekchim-Kharkov, Ukraine } \\
\hline 49 & $\begin{array}{l}\text { rectal } \\
\text { suppositories }\end{array}$ & $\begin{array}{l}\text { non-transparent } \\
\text { blister pack with PVC-film }\end{array}$ & Prostatilen-zinc 30 mg/100 mg/100 mg №10 \\
\hline 50 & $\begin{array}{l}\text { rectal } \\
\text { suppositories }\end{array}$ & $\begin{array}{l}\text { non-transparent } \\
\text { blister pack with PVC-film }\end{array}$ & Bethiolum 15 mg/200 mg №10 \\
\hline 51 & $\begin{array}{l}\text { rectal } \\
\text { suppositories }\end{array}$ & $\begin{array}{l}\text { non-transparent } \\
\text { blister pack with PVC-film }\end{array}$ & No-H-sha 40 mg №10 \\
\hline 52 & $\begin{array}{l}\text { rectal } \\
\text { suppositories }\end{array}$ & $\begin{array}{l}\text { non-transparent } \\
\text { blister pack with PVC-film }\end{array}$ & Anaesthezol №5 \\
\hline
\end{tabular}


Victor Demyanenko, Dmitry Demyanenko, Svetlana Breusova et al.

\begin{tabular}{|c|c|c|c|c|}
\hline 53 & $\begin{array}{l}\text { rectal } \\
\text { suppositories }\end{array}$ & $\begin{array}{l}\text { non-transparent } \\
\text { blister pack with PVC-film }\end{array}$ & \multicolumn{2}{|c|}{ Prostatilen 30 mg №10 } \\
\hline 54 & $\begin{array}{l}\text { rectal } \\
\text { suppositories }\end{array}$ & $\begin{array}{l}\text { non-transparent } \\
\text { blister pack with PVC-film }\end{array}$ & \multicolumn{2}{|c|}{ Hippophaes oleum 350 mg №10 } \\
\hline 55 & $\begin{array}{l}\text { vaginal } \\
\text { suppositories }\end{array}$ & $\begin{array}{l}\text { non-transparent } \\
\text { blister pack with PVC-film }\end{array}$ & \multicolumn{2}{|c|}{ Klioron 16 mg №10 } \\
\hline 56 & $\begin{array}{l}\text { rectal/vaginal } \\
\text { suppositories }\end{array}$ & $\begin{array}{l}\text { non-transparent } \\
\text { blister pack with PVC-film }\end{array}$ & \multicolumn{2}{|c|}{ Tamistol 15 mg №5 } \\
\hline \multicolumn{5}{|c|}{ Nizhpharm Ltd., Russian Federation } \\
\hline 57 & $\begin{array}{l}\text { rectal } \\
\text { suppositories }\end{array}$ & $\begin{array}{l}\text { non-transparent } \\
\text { blister pack with PVC-film }\end{array}$ & \multicolumn{2}{|c|}{ Papaverin 20 mg №10 } \\
\hline 58 & $\begin{array}{l}\text { vaginal } \\
\text { suppositories }\end{array}$ & $\begin{array}{l}\text { non-transparent } \\
\text { blister pack with PVC-film }\end{array}$ & \multicolumn{2}{|c|}{ Livarole $400 \mathrm{mg}$ №5 } \\
\hline 59 & $\begin{array}{l}\text { vaginal } \\
\text { suppositories }\end{array}$ & $\begin{array}{l}\text { non-transparent } \\
\text { blister pack with PVC-film }\end{array}$ & \multicolumn{2}{|c|}{ Hexicon 16 mg №10 } \\
\hline 60 & $\begin{array}{l}\text { rectal } \\
\text { suppositories }\end{array}$ & $\begin{array}{l}\text { non-transparent } \\
\text { blister pack with PVC-film }\end{array}$ & \multicolumn{2}{|c|}{ Hippophaes oleum 500 mg №10 } \\
\hline 61 & $\begin{array}{l}\text { rectal } \\
\text { suppositories }\end{array}$ & $\begin{array}{l}\text { non-transparent } \\
\text { blister pack with PVC-film }\end{array}$ & \multicolumn{2}{|c|}{ Vitaprostum 50 mg №10 } \\
\hline 62 & $\begin{array}{l}\text { vaginal } \\
\text { suppositories }\end{array}$ & $\begin{array}{l}\text { non-transparent } \\
\text { blister pack with PVC-film }\end{array}$ & \multicolumn{2}{|c|}{ Benatex 18.9 mg №10 } \\
\hline 63 & $\begin{array}{l}\text { vaginal } \\
\text { suppositories }\end{array}$ & $\begin{array}{l}\text { non-transparent } \\
\text { blister pack with PVC-film }\end{array}$ & \multicolumn{2}{|c|}{ Depanthol 100 mg / 16 mg №10 } \\
\hline 64 & $\begin{array}{l}\text { rectal } \\
\text { suppositories }\end{array}$ & $\begin{array}{l}\text { non-transparent } \\
\text { blister pack with PVC-film }\end{array}$ & \multicolumn{2}{|c|}{ Cefeconum D 250 mg, 100 mg, №10 } \\
\hline 65 & $\begin{array}{l}\text { rectal } \\
\text { suppositories }\end{array}$ & $\begin{array}{l}\text { non-transparent } \\
\text { blister pack with PVC-film }\end{array}$ & \multicolumn{2}{|c|}{ Glycerol 2110 mg, 1240 mg №10 } \\
\hline \multicolumn{3}{|c|}{$\begin{array}{l}\text { According to the data in the Table } 2 \text { we can con } \\
\text { e that all samples passed the first } 6 \text { stages of in } \\
\text { tion analysis successfully. }\end{array}$} & \multicolumn{2}{|c|}{$\begin{array}{l}\text { According to the data in the Table } 2 \text { we can con- } \\
\text { e that all samples passed the first } 6 \text { stages of in- } \\
\text { tion analysis successfully. }\end{array}$} \\
\hline $\begin{array}{l}\text { Number } \\
\text { of stage }\end{array}$ & \multicolumn{3}{|c|}{ Parameter to be tested } & Results \\
\hline 1 & \multicolumn{3}{|c|}{ Accompanying documents for the incoming goods } & Conforms to the requirements \\
\hline 2 & \multicolumn{3}{|c|}{$\begin{array}{l}\text { Range, quantity and quality of the goods specified in the ac- } \\
\text { companying documents and the ones actually received }\end{array}$} & Conforms to the requirements \\
\hline 3 & \multicolumn{3}{|c|}{ Organoleptic (visual) control of the product packaging } & Conforms to the requirements \\
\hline 4 & \multicolumn{3}{|c|}{ Product labeling } & Conforms to the requirements \\
\hline 5 & \multicolumn{3}{|l|}{ Product barcode } & Conforms to the requirements \\
\hline 6 & \multicolumn{3}{|c|}{ Contents of the goods } & Conforms to the requirements \\
\hline 7 & \multicolumn{3}{|c|}{ Organoleptic (visual) control of the drugs } & $\begin{array}{l}\text { Samples }(4-8,14-15,26-32,39-43) \\
\text { satisfy the requirements. } \\
\text { Samples }(1-3,9-13,16-25,33 \\
\text { - } 38,44-65) \text { cannot be visual- } \\
\text { ly evaluated for quality of the } \\
\text { formulation. }\end{array}$ \\
\hline
\end{tabular}

Scripta Scientifica Pharmaceutica, vol. 3, No. 1, 2016, pp. 60-72 
The possibility of visual control of the medicines (stage 7) depends, first of all, on the properties of the primary packaging containers, namely, their transparency. As it can be seen from our results, 46 samples out of 65 (or 71\%) cannot be visually identified and their appearance is impossible to check because of the opacity of the containers. When it comes to different forms $53 \%$ of studied tablet drugs, $88 \%$ of the eye drops and $100 \%$ of the suppositories cannot be evaluated visually. Analyzing drugs from different manufacturers we found that Sandoz and Lek produce 3 brand names (tablets) in non-transparent blister packs out of the 8 ones researched, Alcon-Couvreur (eye drops) - 5 out of 7, Krка Novo-Mesto (tablets) -10 out of 17, Berlin-Chemie (tablets) -6 out of 11, Pharmak, Ukraine (eye drops) - all 5 of them, Lekchim-Kharkov, Ukraine (suppositories) - all 8 of them, Nizhpharm, Russia ((suppositories) - all 9.

This means that we are not able to properly evaluate such drugs while placed into primary packaging. Even the containers of most of the eye drops were made from opaque plastic, whereas according to the GMP requirements they should be as transparent as possible.

\section{CONCLUSIONS}

Based on the inspection analysis of the accompanying documentation, quantity, packaging, labeling, barcodes and completeness of randomly selected 65 drug samples produced by different manufacturers in tablet, drop and suppository forms, we can conclude that all of them complied with the requirements of the normative documentation at the first 6 stages of inspection. However, it was impossible to evaluate $71 \%$ of the studied samples by the parameter "Appearance" because of the non-transparence of their primary containers. The results of the research will play an important role in the development of advanced kinds of packaging which can allow proper identification and evaluation of drug quality in various forms.

\section{REFERENCES}

1. Organization for Economic Cooperation and Development (OECD). The economic im-pact of counterfeiting and piracy, 2008.
2. Woods K. Anti counterfeiting strategy. Medicines and healthcare products regulatory agency (MHRA) UK 2007-2010. p. 1-42.

3. Swaminath G. Faking it-II: Countering and preventing counterfeiting of drugs. Indian J Psychiatry. 2009;51:9-11.

4. Counterfeit medicines. QA counterfeit. World Health Organization (WHO) 2009. Avail-able from: http://www.who.int/medicines/services/ counterfeit/faqs/QACounterfeit-october 2009.pdf.

5. Shah RY, Prajapati PN, Agrawal YK. Anticounterfeit packaging technologies. J. Adv. Pharm. Tech. Res. 2010;1(4):368-373. Available from: http://www. japtr.org

6. Benbasat AY. A survey of current optical security techniques. Massachusetts: MIT Media Lab; 1999. p. $1-20$.

7. Deisingh AK. Pharmaceutical counterfeiting. Tutorial Review. The Analyst. The Royal society of chemistry. 2005;130:271-9. Available from: http:// www.rsc.org/analyst.

8. Jotcham R. Understanding and evaluating security technologies for pharmaceuticals, in combating Pharmaceutical fraud and counterfeiting. SMI conference documentation. London: SMI publishing; 2003.

9. Ustanso A. RFID technology: A Paradigm shift in business. In: Durmuşoğlu MB, Dr. Cengiz K, Dessouky MI, Süer GA, Eid S, editors. Proceedings of the 35th International Confer-ence on Computers and Industrial Engineering; 2005 June 19-22; Istanbul: Istanbul Technical University; 2005. p. 2065-70.

10. Choi SH, Poon CH. An RFID based anti counterfeiting system IAENG. Int J Comput Sci. 2008;35:12.

11. Koroneos G. FDA opens door to RFID packaging. Pharm Technol. 2004;28:17.

12. Mehta R. Packaging professional magazine. Biometric fingerprints for anti counterfeit-ing. 2007. Available from: http://www.iom3.org/news/ taking-fingerprints.

13. Vetiutneva NA, Ubogov SG, Budnikova TN, Pilipchuk LB, Fedorova LA, Todorova VI, et al. The normative legal adjusting in the sector of the quality assurance of medicinal products in Ukraine: retrospective analysis. Pharmaceutical Journal. 2013;4:9-16. [Нормативно-правове регулювання 
Victor Demyanenko, Dmitry Demyanenko, Svetlana Breusova et al.

у сфері забезпечення якості лікарських засобів в Україні: ретроспективний аналіз]. Ukrainian.

14. Medicine remedies. Packing, marking, transportation and storage, GOST 17768-90 (January 01, 1992). Moscow: Publishing House of Standards; 1991. [Средства лекарственные. Упаковка, маркировка, транспортирование и хранение : ГOCT 17768-90]. Russian.

15. Demyanenko VG, Afanasyeva VA, Proskochilo AV, Breusova SV. Medical and Pharma-ceutical Commodity Science, practical handbook. Prof. Demyanenko VG, editor. Kyiv: Medi-cina; 2010. [Медицинское и фармацевтическое товароведение : практикум]. Russian.

16. Vetiutneva NA, Ubogov SG, Pilipchuk LB, Budnikova TN, Fedorova LA, Todorova VI, et al. The modern state and development trends of the normative legal adjusting in the sector of the quality assurance of medicinal products. Pharmaceutical Journal. 2014;3:66-72. [Сучасний стан та тенденції розвитку нормативно-правового регулювання у сфері забезпечення якості лікарських засобів]. Ukrainian.

17. On storage organization of different groups of medicines and medical devices in pharma-cies, Order of Ministry of Public Health of Ukraine No. 44 (March 16, 1993). [Про організацію зберігання в аптечних установах різних груп лікарських засобів та виробів медичного призначення : наказ МО3 України № 44 від 16 березня 1993]. Ukrainian.

18. On approval of Instruction on quality control of medicinal products in wholesale and retail trade, Order of Ministry of Public Health of Ukraine No. 436 (October 30, 2001). Available from: http://zakon.rada.gov.ua/laws/show/z010702. [Про затвердження Інструкції про порядок контролю якості лікарських засобів під час оптової та роздрібної торгівлі : наказ МО3 України № 436 від 30.10.2001]. Ukrainian.

19. On medical products, Law of Ukraine No. 123/96BP (April 04, 1996). Available from: http:// zakon3.rada.gov.ua/laws/show/123/96-вр. [Про лікарські засоби : Закон України № 123/96ВР від 04.04.1996]. Ukrainian.

20. Legal acts of Ukraine. Available from: http:// mozdocs.kiev.ua. [Нормативно-директивні документи MO3 України]. Ukrainian.

21. Laws of Ukraine. Available from: http://zakon4. rada.gov.ua. [Законодавство України]. Ukrainian.
22. On approval of the rules for quality control of medicinal products in wholesale and retail trade, Order of Ministry of Public Health of Ukraine No. 677 (September 29, 2014). Available from: http://www.apteka.ua/article/316075. [Про затвердження Порядку контролю якості лікарських засобів під час оптової та роздрібної торгівлі : наказ МО3 України № 677 від 29.09.2014]. Ukrainian.

23. State Enterprise "Scientific and Expert Pharmacopoeial Center". State Pharmacopoeia of Ukraine. 1st ed., suppl. 1. Kharkiv: Rireg; 2004. 520 p. [Державна Фармакопея України]. Ukrainian.

24. Azgaldov GG. Theory and practice of quality evaluation of goods (bases of qualimetry). Moscow: Economica; 1982. [Теория и практика оценки качества товаров (основы квалиметрии)]. Russian.

25. Gryzodub AI, Sur SV. Problems of quality and falsification of drugs. Ukrainian Medical Journal. 2007;3(59):137-144. [Проблемы качества и фальсификации лекарственных средств]. Russian.

26. Gryzodub AI, Sur SV, Georgiyevsky VP. Problems of quality and falsification of drugs. Pharmacom. 2007;2:6-15. [Проблемы качества и фальсификации лекарственных средств]. Russian.

27. Ryschenko OA, Shapovalova VA, Shapovalov VV. Council of Europe Convention «On fighting falsification of medical products and similar crimes that threaten public health» as a source of development forensic pharmacy. Pharmaceutical Journal. 2013;4:39-45. [Конвенція ради Європи «Про боротьбу з фальсифікацією медичної продукції та подібними злочинами, які загрожують здоров'ю населення» як джерело розвитку судової фармаціï]. Ukrainian.

28. Almakayev MS, Shevchenko IV, Shevchenko VA, Bodrenkova NA. Influence of poly-ethylene primary packaging systems on stability of parenteral drugs based on topical anesthetics. Management, economy and quality assurance in pharmacy. 2009;1(3):4-8. [Влияние полиэтиленовых контейнеров на стабильность парентеральных лекарственных средств на основе местных анестетиков]. Russian.

29. Krutskikh TV, Shalamay AS. Study of the effect of packaging on quality tablets of Alto-bar during storage. Management, economy and quality assur- 
ance in pharmacy. 2015;4(42):42-44. [Вивчення

впливу виду упаковки на якість таблеток

Альтабор під час зберігання]. Ukrainian.

30. Stolypin V, Gurariy L. GMP requirements to drug packaging (part 1). The Industry. 2004;2:89-92.

Available from: www.erecton.ru/ publications/2-04.

pdf. [Требования GMP к упаковке ЛС (часть 1)].

Russian.

31. Madsen R, Cherris R, Shabushnig J, Hunt D. Visible Particulates in Injections - A His-tory and Proposal to Revise USP Injections. USP Pharmacopeial Forum. 2009 Sept-Oct;35(5):1383-7. Available from: http://www.baipharma.com/documents/PF35-5-_ StimArticle-3Chapter1VisibleParticulatesinInjections.pdf.

32. Tool for visual inspection of medicines. Available from: http://www.whpa.org/toolkit_beaware_inspection.pdf. 